\title{
HUBUNGAN SECURE ATTACHMENT DAN PROBLEM SOLVING ABILITY DENGAN PRESTASI AKADEMIK MAHASISWA
}

\author{
Hetti Sari Ramadhani 1), Adnani Budi Utami2), Moh Fais Imron ${ }^{3)}$, Nurul Qomariah4) \\ 1,2,3,4 Psikologi, Universitas 17 Agustus 1945 \\ Surabaya \\ Email: ${ }^{1}$ hetti_sari@untag-sby.ac.id
}

\begin{abstract}
Abstrak
Prestasi akademik menjadi salah satu indikator keberhasilan dalam proses belajar mengajar sehingga perlu menjadi perhatian untuk mencari predictor dalam menentukan peningkatan prestasi akademik. Penelitian ini bertujuan untuk melihat adanya hubungan secure attachment dan problem solving ability dengan prestasi akademik mahasiswa. Subyek penelitian menggunakan 130 mahasiswa aktif angkatan 2016-2018 namun kemudian diambil secara purposive sampling dengan kriteria mahasiswa tergolong dalam kelompok secure attachment yaitu memiliki skor tinggi pada aspek close dan depend serta skor rendah pada anxiety sebanyak 19 orang. Data dikumpulkan dengan skala adaptasi adult attachment dari Collins (1996), skala adaptasi problem solving ability dari Independent-Interdependent Problem-Solving Scale (IIPSS; pronounced "ipsus"; Rubin, Watt, \& Ramelli, 2012) dan data indeks prestasi akademik mahasiswa. Data dianalisis menggunakan Regresi. Hasil penelitian menunjukkan tidak ada hubungan antara secure attachmen dan problem solving ability dengan prestasi akademik mahasiswa dari nilai Sig. 0,365 >0,05. Namun ada hubungan antara secure attachment dan prestasi akademik dari nilai Sig. 0,044 <0,05. Hal ini dapat disimpulkan bahwa prestasi akademik mahasiswa dapat dikaitkan dengan secure attachment.
\end{abstract}

Keywords: Prestasi, Akademik, Attachment, Problem Solving

\begin{abstract}
Academic achievement to be one indicator of success in the teaching and learning process needs to be a concern to look for predictors in determining the improvement of academic achievement. This research shows that there is relationship between secure attachment and problem solving ability with students' academic achievement. The research subjects used 130 active students of the 2016-2018 class, but then it was taken by purposive sample with students belonging to the secure attachment group that had a high score on the aspect of closing and depended on a low score on anxiety of 19 people. Data were collected with an adult attachment adaptation scale from Collins (1996), an adaptation scale for problem solving ability from the Independent- Interdependent Problem-Solving Scale (IIPSS; pronounced "ipsus"; Rubin, Watt, \& Ramelli, 2012) and student academic achievement index data. Data were analyzed using Regression. The results of the study showed there was no relationship between secure attachments and problem solving abilities with student academic achievement from the Sig. 0.365>0.05. However there is a relationship between secure attachment and academic achievement from Sig. $0.044<0.05$. It can be concluded that academic achievement can be completed by secure attachment.
\end{abstract}

Keywords: Achievement, Academic, Attachment, Problem Solving 


\section{PENDAHULUAN}

Mahasiswa berprestasi secara akademik menjadi kebanggaan suatu institusi perguruan tinggi yang menyelenggarakan proses belajar mengajar. Prestasi akademik berdasarkan taksonomi bloom merupakan perubahan perilaku yang berasal dari aspek kognitif, afektif dan psikomotorik dan menjadi parameter keberhasilan mahasiswa dalam belajar (Sugiyanto, 2007). Menurut Suryabrata (2012) Prestasi akademik ditunjukkan dalam nilai tes atau kuantitatif berupa angka yang muncul dari pengetahuan dan keterampilan mahasiswa dalam matakuliah tertentu.

Banyak cara yang dilakukan oleh praktisi pendidikan dalam hal ini dosen untuk meningkatkan prestasi akademik mahasiswa diantaranya penerapan metode yang bervariasi, pengembangan materi kuliah berdasarkan riset, praktek pembelajaran secara aplikatif atau penggunaan penjelasan kontekstual dalam diskusi di kelas. Namun belum banyak mahasiswa yang bisa mencapai hasil belajar yang memuaskan selama satu semester. Hal ini terlihat dari hasil nilai mahasiswa yang masuk kategori kurang atau bahkan harus mengulang di semester depan.

Kesulitan mahasiswa mencapai prestasi akademik dapat dilihat dari berbagai masalah yang terjadi dalam diri mahasiswa tersebut dan segera diidentifikasi agar menjadi intervensi yang tepat ke depan. Tidak sedikit mahasiswa mengalami penurunan indeks prestasi akademik atau bahkan tidak mampu mencapai hasil yang diharapkan dengan alasan yang cukup beragam diantaranya tidak mampu menyelesaikan tugas yang dibebankan pada suatu mata kuliah tertentu, tidak mampu menjalin kelompok saat proses belajar di kelas, tidak suka dengan dosen pengajar, tidak mampu mengikuti proses belajar karena banyaknya hal yag dipikirkan baik teman, keluarga, pekerjaan bahkan tidak jarang mahasiswa tidak memiliki harapan pada matakuliah tersebut. Keadaan ini menunjukkan kondisi secure attachment yang buruk pada diri mahasiswa.

Secure attachment yang baik ditunjukkan dengan sikap mudah bergaul dengan rekan, mampu membangun persahabatan, mampu menyelesaikan permasalahan dengan dengan orang lain, memiliki harga diri yang baik serta mampu bersikap baik pada orang lain. Mahasiswa dengan secure attachment yang baik terlihat lebih mudah menjalani rutinitasnya. Sebaliknya mahasiswa dengan secure attachment yang buruk akan terlihat sulit menjalani rutinitasnya. Collins Fernandez \& Dufey (2015) menjelaskan pribadi yang memiliki secure attachment adalah pribadi yang merasa berharga dan dicintai, mampu membangun hubungan yang baik dengan orang lain serta memiliki kedekatan dengan orang-orang sekitar.

Permasalahan belajar juga bisa dilihat dari kemampuan mahasiswa dalam memecahkan masalah atau problem solving ability selama menjalani perkuliahan. Tidak menutup kemungkinan selama proses belajar satu semester, mahasiswa mengalami banyak permasalahan dalam dirinya diantaranya materi perkuliahan yang sulit dipahami, materi yang sulit didapat, banyaknya tugas yang menumpuk, perselisihan dengan teman, mengatur waktu, turunnya motivasi belajar, ajakan teman untuk bermain game berlebihan, pacaran, konflik keluarga dsb.

Rubin, M., Watt, S. E., \& Ramelli, M. (2012) menjelaskan problem solving 
ability adalah kemampuan untuk bisa menyelesaikan masalah dan mencapai tujuan yang diinginkan baik dengan dirinya sendiri maupun dengan bantuan orang lain. Menurut Mulyasa (2004) problem solving ability merupakan kemampuan berpikir kritis dan ilmiah dari seorang siswa untuk memecahkan permasalahan serta bisa menemukan konsep esensial dari materi pembelajaran.

Berdasarkan permasalahan tersebut, maka peneliti ingin melanjutkan dalam penelitian yang melihat faktor eksternal secure attachment dan internal problem solving ablity dalam kaitan prestasi akademik mahasiswa dengan judul penelitian Hubungan antara Secure Attachment dan Problem Solving Ability dengan prestasi akademik Mahasiswa Untag Surabaya.

\section{METODE PENELITIAN}

Peneliti ini menggunakan desain penelitian kuantitatif dengan bentuk korelasional untuk melihat adanya hubungan antara secure attachment dan problem solving ability dengan prestasi akademik. Subyek yang digunakan adalah mahasiswa angkatan psikologi angkatan 2016-2018, skala disebar pada 130 mahasiswa aktif dan kemudian dipilih secara purposive sampling sebanyak 19 mahasiswa dengan melihat mahasiswa yang memiliki skor tinggi close dan depend serta rendah pada anxiety pada skala secure attachment.

Pengumpulan data penelitian menggunakan daftar pertanyaan dalam bentuk skala adaptasi adult attachment dari Collins (1996), skala adaptasi problem solving ability dari IndependentInterdependent problem-Solving Scale (IIPSS; pronounced "ipsus"; Rubin, Watt, \& Ramelli, 2012) dan data indeks prestasi akademik mahasiswa. Skala adult attachment dan problem solving ability telah diartikan dalam Bahasa Indonesia dan dilakukan uji validitas dan reliabilitas dengan hasil penghitungan sebagai berikut :

Tabel.1 Hasil uji reliabilitas

\begin{tabular}{|l|l|}
\hline \multicolumn{2}{|l|}{ Reliabilitas } \\
\hline close & close \\
\hline depend & depend \\
\hline anxiety & anxiety \\
\hline Problem solving & Problem solving \\
ability & ability \\
\hline
\end{tabular}

Tabel.2 Hasil Uji Valditas

\begin{tabular}{|l|l|}
\hline Close & nomor item \\
& $1,8,12,13$ \\
& $(0,344-0,532)$ \\
\hline Depend & nomor item \\
& $3,4,9,10,11,15$ \\
& $(0,391-0,657)$ \\
\hline Anxiety & nomor \\
& item7,14,16,18 \\
& $(0,377-0,442)$ \\
\hline Problem solving & Nomor item \\
ability & $2,3,4,6,7,8,9$ \\
& $(0,208-0,319)$ \\
\hline
\end{tabular}

Teknik analisis data menggunakan regresi. Data yang digunakan telah diuji prasyarat normalitas dan linieritas. Hasil penghitungan sebagai berikut :

Tabel.3 Uji Normalitas

\begin{tabular}{|l|l|}
\hline Uji Normalitas & Nilai Sig \\
\hline Attachment & 0,322 \\
\hline Problem solving ability & 0,196 \\
\hline
\end{tabular}

Data menunjukkan berdistribusi normal dengan nilai Sig. > 0,05

Tabel. 4 Uji Linieritas

\begin{tabular}{|l|l|}
\hline Uji Linieritas & Nilai Sig. \\
\hline IPK dengan secure Attachment & 0,772 \\
\hline $\begin{array}{l}\text { IPK dengan Problem } \\
\text { Solving Ability }\end{array}$ & 0,439 \\
\hline
\end{tabular}


Data menunjukkan linier dengan nilai

Sig. $>0,05$

\section{HASIL DAN PEMBAHASAN}

Berdasarkan hasil hitung regresi diperoleh nilai sebagai berikut :

Tabel.5 Hasil Regresi

\begin{tabular}{|l|l|}
\hline Nilai R & 0,561 \\
\hline Nilai Sig. & 0,365 \\
\hline
\end{tabular}

\begin{tabular}{|l|l|}
\hline $\begin{array}{l}\text { Nilai Sig. IPK dan } \\
\text { secure attachment }\end{array}$ & 0,044 \\
\hline $\begin{array}{l}\text { Nilai Sig. IPK dengan } \\
\text { Problem Solving } \\
\text { Ability }\end{array}$ & 0,981 \\
\hline
\end{tabular}

Nilai Sig. 0,365 >0,05 menunjukkan bahwa hipotesis penelitian ditolak yaitu tidak ada hubungan antara secure attachment dan problem solving ability dengan prestasi akademik mahasiswa. Dan pada nilai Sig. 0,044 < 0,05 menunjukkan adanya hubungan positif antara secure attachment dengan prestasi akademik. Hal ini menunjukkan bahwa semakin baik secure attachment yang dimiliki mahasiswa maka semakin tinggi pula prestasi akademik.

Secure Attachment Menurut Ainsworth (1969) adalah keterikatan yang aman secara emosional antara orangtua dengan anak dan sebagai dasar perkembangan psikologis kedepan. Secure Attachment sebagai dasar kelekatan antara orangtua dengan anak dalam bentuk interaksi yang responsive dan sangat berpengaruh pada tumbuh kembang anak hingga masa depannya. Mahasiswa dengan secure attachment yang baik akan menunjukkan perilaku yang menghargai diri sendiri, mampu membangun relasi dengan teman dan dosen, membangun kedekatan dengan orang sekitar, dan menyayangi teman. Sikap ini akan sangat membantu mahasiswa menjalani rutinitas perkuliahan sehingga mahasiswa bersemangat dalam mengikuti perkuliahan, menghargai setiap pengetahuan dan berusaha berinteraksi dengan teman dan dosen untuk mencapai hasil belajar yang memuaskan.

Hoffman (2017) menjelaskan dalam buku Raising a Secure Child bahwa seseorang dengan secure attachment yang baik menunjukkan : a) sikap nyaman saat bersama kedua orangtua, b) jarang memiliki kemarahan pada orangtua, c) mampu menyelesaikan permasalahan dengan teman, d) memiliki hubungan yang lebih baik dengan saudara, e) memiliki harga diri yang lebih tinggi, f) optimis, g) percaya pada orang yang ia sayangi, h) ramah pada orang sekitar. Ainsworth (1969) menjelaskan seseorang dengan secure attachment terlihat dengan karakteristik : a) memiliki kepercayaan ketika berhubungan dengan orang lain, b) memiliki konsep diri yang bagus, c) merasa nyaman untuk berbagi perasaan dengan orang lain, d) peduli dengan orang lain.

\section{KESIMPULAN}

Penelitian ini menunjukkan adanya hubungan positif antara secure attachment dengan prestasi akademik dengan nilai Sig. $0,044<0,05$. Hal ini menunjukkan bahwa semakin baik secure attachment yang dimiliki mahasiswa maka semakin tinggi pula prestasi akademik. Secure attachment seorang anak diharapkan terus dijaga dalam keluarga sehingga bisa menjadi pendukung dalam kenerhasilan belajar.

Saran penelitian ditujukan pada keluarga dan orangtua untuk senantiasa menjaga hubungan interaksi anak dan 
orangtua terutama di usia awal anak. Kelekatan dasar inilah yang membangun diri positif pada anak hingga dewasa sehingga anak bisa mencapai hasil studi dengan baik. Hal ini sejalan dengan Collins Fernandez \& Dufey (2015) yang menjelaskan pribadi dengan secure attachment yang baik menunjukkan pribadi yang merasa berharga dan dicintai, mampu membangun hubungan yang baik dengan orang lain serta memiliki kedekatan dengan orang-orang sekitar.

Peneliti sadar akan kelemahan dalam penelitian ini yaitu memiliki alat ukur problem solving ability yang kurang valid sehingga saran untuk peneliti selanjutnya bisa mengembangkan aspek lain tentang prestasi akademik.

\section{REFERENSI}

Ainsworth, Mary D. Salter. 1969. Object

Relations, Dependency, and Attachment: A Theoretical Review of The Infant-Mother Relationship. Journal: Child Development, Johns Hopkins University, 1969, 40, 9691025.

Desmita, R. 2008. Psikologi Perkembangan. Bandung:

PT.Remaja Rosdakarya.

Fernandez \& Dufey, 2015. Adaptation of Collins' Revised Adult Attachment Dimensional Scale to the Chilean Context psychology /Psicologia Refl exão e Crítica, 28(2), 242-252.

Hoffman. 2017. Raising a Secure Child. The Guilford Press 280- 298.

Neuman, W.L. 2000. Social Research Methods Quantitative and Qualitative Approaches $\left(4^{\text {th }}\right.$ ed). Boston: Pearson Educational Inc.

Rubin, M., Watt, S. E., \& Ramelli, M. 2012. Immigrants' social Integration as a function of approach avoidance orientation andproblem-solving style. International Journal of Intercultural Relations,36, 498 505. 
Volume 71, Nomor 2, 1 Desember 2019 